\title{
EVALUASI KINERJA KEUANGAN PERUSAHAAN DAERAH AIR MINUM (Studi Kasus PDAM Tirta Perwitasari Kabupaten Purworejo)
}

\section{FINANCIAL PERFORMANCE EVALUATION OF REGIONAL WATER COMPANY (Case Study on PDAM Tirta Perwitasari District of Purworejo)}

\author{
Shabo Hernoko \\ Pusat Litbang Pembangunan dan Keuangan Daerah \\ Badan Penelitian dan Pengembangan Kementerian Dalam Negeri \\ Jalan Kramat Raya No. 132, Senen - Jakarta Pusat \\ e-mail: shabotage@ymail.com
}

Diterima: 23 Juli 2012; direvisi: 8 Agustus 2012; disetujui: 10 Agustus 2012

\begin{abstract}
Abstrak
Tujuan penelitian ini adalah untuk mengetahui perkembangan kinerja keuangan PDAM Tirta Perwitasari selama kurun waktu 2006-2010. Penelitian ini mempergunakan metode kualitatif untuk memperoleh gambaran tentang kinerja keuangan terkait implementasi dan masalah yang dihadapi. Penilaian terhadap kinerja keuangan PDAM diatur dalam Kepmendagri No. 47 Tahun 1999 tentang Pedoman Penilaian Kinerja Perusahaan Daerah Air Minum, dan analisis Common Size dipergunakan untuk menginterpretasikan laporan keuangan yang dimiliki perusahaan sehingga diketahui perkembangannya selama periode penelitian. Hasil penelitian menunjukkan, perusahaan sangat likuid untuk melunasi utangutang jangka pendeknya, dalam kondisi solvable, namun terdapat kelebihan biaya operasional dari yang seharusnya setiap tahunnya. Berdasarkan analisis Common Size, perusahaan pada tahun 2006 mengalami kerugian usaha, baru kemudian memperoleh laba usaha mulai tahun 2007 hingga 2010.

Kata kunci: evaluasi, likuiditas, solvabilitas, rentabilitas, PDAM.
\end{abstract}

\begin{abstract}
The study aims to determine the development of the financial performance of PDAM Tirta Perwitasari, during the period from year 2006-2010. The study used qualitative methods to obtain an overview of the financial performance, related to the implementation and problems encountered. An assessment of the financial performance of the PDAM set in Kepmendagri No. 47 Year 1999 about Pedoman Penilaian Kinerja Perusahaan Daerah Air Minum, and the Common Size analysis is used to interpret the financial statements of the company to determine the development of the financial performance during the study period. The results showed that, highly liquid companies to pay off short-term debts, the solvable conditions, but there is excess operating costs annually. Based on the analysis of Common Size, the company in 2006; suffered business loss, then gain in operating income from year 2007-2010.
\end{abstract}

Keywords: evaluation, liquidity, solvency, profitability, PDAM.

\section{PENDAHULUAN}

Salah satu sumber dana untuk mendukung keuangan daerah adalah hasil perusahaan milik daerah. Sebagaimana diketahui bahwa tugas dan peranan Badan Usaha Milik Daerah (BUMD) adalah mendorong kegiatan ekonomi daerah, menciptakan kesempatan kerja, menyediakan jasa pelayanan sosial dan memberikan kontribusi bagi Pendapatan Asli Daerah (PAD). Perusahaan daerah adalah BUMD yang merupakan pengelola kekayaan daerah yang dipisahkan, berwenang dan bertanggungjawab atas penyelenggaraan administrasi dan penggunaannya, sehingga perusahaan milik daerah merupakan bagian yang cukup penting dalam menunjang PAD. Wahyudin dan Muryati (2001), menyatakan bahwa peranan perusahaan daerah diwujudkan dalam bentuk pembagian laba yang disetorkan kepada Pemerintah Daerah yang bersangkutan dan dimasukkan dalam Anggaran Pendapatan dan Belanja Daerah (APBD) sebagai sumber pembiayaan bagi kegiatan pembangunan di daerah.

Perusahaan Daerah Air Minum (PDAM) dihadapkan pada persoalan yang dilematis karena keberadaannya sebagai salah satu BUMD yang dimiliki oleh Pemerintah Daerah (Pemda). PDAM diharapkan selalu memberikan kontribusi laba BUMD terhadap PAD, namun masih banyak PDAM belum mampu memenuhi tuntutan tersebut karena keterbatasan di bidang keuangan, operasional dan administrasi. Bahkan dalam kenyataannya, banyak PDAM di berbagai daerah justru mengalami kerugian usaha.

Berdasarkan data tahun 2001, usaha-usaha pemerintah telah dilakukan selama lebih dari 15 tahun dengan anggaran yang cukup besar untuk memperbaiki manajemen PDAM baik dengan konsultan lokal maupun luar negeri namun tidak membawa hasil. Bahkan dapat dikatakan bahwa $90 \%$ 
dari 296 PDAM telah menjadi pasien yang tidak mungkin sembuh (Rismianto: 2001).

Kita sadari bersama bahwa air merupakan kebutuhan dasar sehari-hari yang harus dipenuhi. Namun hingga beberapa waktu terakhir, dikutip dari tulisan Suhendra (2012) dalam detik.com, Boediono menuturkan bahwa Indonesia masih harus berjuang keras meningkatkan produksi air bersih dan air minum yang sehat, karena dari 300 PDAM yang ada di Indonesia (hingga tahun 2012) hanya 25\% yang tergolong baik. Masalah manajemen menjadi kunci permasalahan ini, baik aspek personalia, sistem, hubungan antara PDAM dan pemerintah.

BUMD di era otonomi masih menjadi tumpuan harapan untuk mengisi kas pemerintah daerah, tetapi penerimaan dari sumber ini tidak seperti yang diharapkan. Kondisi ini juga dialami oleh Pemerintah Kabupaten Purworejo.

Terlihat bahwa begitu kecilnya kontribusi laba BUMD terhadap PAD; dan PDAM Tirta Perwitasari hanya memberikan kontribusi sebesar rata-rata $0,32 \%$ dalam periode tahun 2000-2004. dan menganalisis elastisitas PDRB per kapita riil terhadap laba riil PDAM. Kesimpulan yang diperoleh adalah bahwa kinerja PDAM Delta Tirta Kabupaten Sidoarjo selama sepuluh tahun tingkat keberhasilannya mempunyai nilai cukup kecuali tahun 1993 dan 1995 mempunyai nilai baik.

Kemudian Sefraningsih (2001) di dalam penelitian yang dilakukannya di PDAM Tirta Musi Kabupaten Rejang Lebong, menghasilkan beberapa kesimpulan. Kinerja aspek keuangan dikategorikan kurang karena biaya penyusutan aktiva tetap sangat besar dan penjualan air yang rendah, sehingga terjadi kerugian setiap tahunnya pada periode pengamatan 1995-1999. Kinerja aspek operasional kurang, disebabkan cakupan pelayanan yang rendah, kualitas air distribusi rendah, kontinuitas air tidak merata, tingkat kebocoran yang relatif tinggi di atas batas yang ditetapkan, yaitu $20 \%$, peneraan meter yang tidak konsisten, lamanya kecepatan penyambungan baru, pengaduan pelanggan belum semua ditangani dan rasio karyawan per 1000 pelanggan cukup tinggi. Kinerja aspek administrasi kurang disebabkan rencana

Tabel 1. Persentase Komponen PAD

\begin{tabular}{|clccccc|}
\hline No. & Komponen PAD & $\mathbf{2 0 0 0}(\%)$ & $\mathbf{2 0 0 1}(\%)$ & $\mathbf{2 0 0 2}(\%)$ & $\mathbf{2 0 0 3}(\%)$ & $\mathbf{2 0 0 4}(\%)$ \\
\hline 1. & Pajak Daerah & 14,12 & 14,75 & 15,70 & 16,86 & 18,47 \\
2. & Retribusi Daerah & 78,06 & 65,03 & 62,80 & 62,80 & 62,27 \\
3. & Laba BUMD: & & & & & \\
& PDAM & 0,48 & 0,28 & 0,275 & 0,294 & 0,27 \\
& PD Apotik Daerah & 0,22 & 0,23 & 0,210 & 0,245 & 0,20 \\
& Bank Pasar & 0,23 & 0,16 & 0,260 & 0,081 & - \\
& BKK & 0,68 & 0,32 & 0,205 & 0,140 & 0,13 \\
4. & Lain-lain PAD yang sah & 6,21 & 19,23 & 20,55 & 19,58 & 18,65 \\
& $\quad$ Jumlah & 100,00 & 100,00 & 100,00 & 100,00 & 100,00 \\
\hline
\end{tabular}

Sumber: Target dan realisasi pendapatan daerah Kabupaten Purworejo 2000-2004, data diolah.

Sebagai informasi bahwasannya PDAM Tirta Perwitasari Kabupaten Purworejo, telah menjalankan usahanya selama 37 tahun untuk melayani masyarakat dalam memenuhi kebutuhan air bersih, namun hingga saat ini baru bisa melayani $17 \%$ dari total jumlah penduduk kabupaten Purworejo.

Aturan terkait kontribusi laba BUMD terhadap PAD tersebut, semakin dipertegas ke dalam Peraturan Daerah (Perda) Kabupaten Purworejo Nomor 15 Tahun 2011 tentang Perusahaan Daerah Air Minum Tirta Perwitasari pasal 56 ayat (1) bahwa laba bersih PDAM yang telah disahkan oleh Bupati, penggunaannya ditetapkan sebagai berikut:

a. Pemerintah daerah $55 \%$ (lima puluh lima persen);

b. Cadangan umum $10 \%$ (sepuluh persen);

c. Cadangan tujuan $10 \%$ (sepuluh persen);

d. Dana kesejahteraan $10 \%$ (sepuluh persen);

e. Jasa produksi $15 \%$ (lima belas persen).

Rachmawati (2001) telah melakukan penelitian tentang kinerja PDAM Delta Tirta dan faktor-faktor yang mempengaruhinya (studi kasus di Kabupaten Sidoarjo) tahun 1990-1999. Penelitian tersebut mengukur kinerja keuangan, operasional, administrasi jangka panjang, rencana organisasi dan uraian tugas, pelaksanaan prosedur operasi standar, pelaksanaan gambar nyata laksana dipedomani sebagian, sedangkan hasil temuan dari Instansi Pemeriksa tidak ditindaklanjuti.

Namun hasil dari berbagai penelitian yang telah ada tersebut tidak berlaku umum, dengan pengertian bahwa kesimpulan yang diperoleh melalui penelitian tersebut tidak dapat digunakan untuk menjelaskan kinerja keuangan PDAM Tirta Perwitasari Kabupaten Purworejo. Di dalam penelitian ini terdapat perbedaan dengan penelitian terdahulu, yaitu objek yang diteliti, lokasi penelitian dan periode pengamatan selama lima tahun yakni mulai tahun 2006 sampai dengan tahun 2010. Penelitian ini menjadi penting untuk dilakukan, mengingat kontribusi PDAM terhadap PAD yang rendah, padahal begitu banyak peluang strategis yang dimiliki oleh BUMD, di antaranya bahwa BUMD memiliki captive market dan bargaining power karena notabene kepemilikannya di tangan Pemda.

Fenomena yang terjadi saat ini adalah, bahwa masih terdapat PDAM yang belum mampu memenuhi tuntutan untuk berkontribusi terhadap PAD, karena 
keterbatasan di bidang keuangan, operasional dan administrasi. Lebih ironisnya lagi, ternyata masih banyak PDAM di berbagai daerah yang justru mengalami kerugian usaha. Berangkat dari berbagai masalah tersebut, maka yang menjadi research question adalah bagaimana perkembangan kinerja keuangan PDAM Tirta Perwitasari selama kurun waktu 2006-2010?

Berdasarkan perumusan masalah tersebut, maka tujuan dari penelitian ini adalah untuk mengetahui perkembangan kinerja keuangan PDAM Tirta Perwitasari selama kurun waktu 2006-2010.

Perusahaan Daerah atau BUMD menurut Keputusan Menteri Dalam Negeri dan Otonomi Daerah No. 43 Tahun 2000 tentang Pedoman Kerjasama Perusahaan Daerah dengan Pihak Ketiga, adalah suatu badan usaha yang modalnya merupakan kekayaan daerah yang dipisahkan. Pendirian BUMD tersebut diprakarsai oleh Pemerintah Daerah. Sesuai dengan Peraturan Pemerintah (PP) No. 14 Tahun 1987 tentang Penyerahan Sebagian Urusan Pemerintah di Bidang Pekerjaan Umum kepada Daerah, maka pelayanan air minum diserahkan kepada Pemerintah Daerah Tingkat II sebagai urusan Pemerintah Daerah. Selanjutnya melalui Peraturan Daerah (Perda) diserahkan pelaksanaannya kepada PDAM.

Perusahaan Daerah Air Minum selanjutnya disingkat PDAM adalah perusahaan milik Daerah Provinsi dan atau Daerah Kota (Keputusan Menteri Dalam Negeri No. 47 Tahun 1999 tentang Pedoman Penilaian Kinerja Perusahaan Daerah Air Minum). PDAM merupakan salah satu BUMD yang bergerak di bidang penyediaan air bersih untuk kebutuhan masyarakat. Keberadaan PDAM sebagai unsur pelayanan publik, harus mengutamakan aspek sosial. Hal ini tercermin di dalam penetapan harga produk lebih mempertimbangkan kemampuan masyarakat, namun dibalik fungsinya sebagai unsur pelayanan publik juga tidak terlepas dari dimensi ekonomi, yaitu mencari keuntungan.

Salah satu cara untuk menilai kinerja perusahaan adalah dengan cara menganalisis laporan keuangan perusahaan yang bersangkutan. Analisis terhadap laporan keuangan suatu perusahaan bermanfaat untuk mengetahui keadaan dan perkembangan keuangan dari perusahaan yang bersangkutan. Dengan mengadakan analisis laporan keuangan perusahaan, keadaan dan perkembangan keuangan dari perusahaan akan dapat diketahui hasilhasil yang telah dicapai pada waktu yang lalu dan waktu yang sedang berjalan. Dengan menggunakan laporan yang diperbandingkan, termasuk data tentang perubahan-perubahan yang terjadi dalam jumlah rupiah, persentase serta trendnya, beberapa rasio secara individu akan membantu dalam menganalisis dan menginterpretasikan posisi keuangan suatu perusahaan (Helfert: 1995).

Untuk mengetahui apakah perusahaan sudah berjalan dengan baik, maka harus diketahui kinerja perusahaannya. Kinerja perusahaan secara sederhana dapat diketahui dari tiga hal (Sutrisno, 2003: 15).

a. Likuiditas, adalah kemampuan perusahaan untuk memenuhi kewajiban-kewajibannya yang harus segera dipenuhi.

b. Solvabilitas, adalah kemampuan perusahaan untuk memenuhi semua kewajibannya apabila perusahaan dilikuidasi.

c. Rentabilitas, adalah adalah kemampuan perusahaan untuk menghasilkan laba selama periode tertentu.

Laporan Keuangan merupakan hasil akhir dari proses akuntansi yang meliputi dua laporan utama (Jusup, 2003: 21).

1. Neraca. Adalah laporan yang menunjukkan posisi keuangan suatu perusahaan pada saat tertentu.

2. Laporan Rugi-Laba. Adalah laporan yang menunjukkan hasil kegiatan perusahaan dalam jangka waktu tertentu.

Kemudian Munawir (2004) mengatakan bahwa laporan keuangan pada dasarnya adalah hasil dari proses akuntansi yang dapat digunakan sebagai alat untuk berkomunikasi antara data keuangan atau aktivitas suatu perusahaan dengan pihak-pihak yang berkepentingan dengan data atau aktivitas perusahaan tersebut. Disusun dengan maksud untuk menyediakan informasi keuangan suatu perusahaan sebagai bahan pertimbangan di dalam mengambil keputusan. Pihakpihak yang berkepentingan tersebut antara lain manajemen, pemilik, kreditor, investor dan pemerintah, serta pihak-pihak lainnya.

Keuangan menjadi salah satu faktor pendukung pelaksanaan otonomi daerah. Berdasarkan UndangUndang (UU) No. 32 Tahun 2004 pasal 157, disebutkan bahwa sumber pendapatan daerah terdiri atas.

a. Pendapatan Asli Daerah, yaitu:

1) Hasil Pajak Daerah;

2) Hasil Retribusi Daerah;

3) Hasil pengelolaan kekayaan daerah yang dipisahkan; dan

4) Lain-lain PAD yang sah;

b. Dana perimbangan; dan

c. Lain-lain pendapatan Daerah yang sah.

Besaran PAD yang diperoleh Pemda dari BUMD tergantung pada besaran laba yang diperoleh BUMD. Meskipun PAD tidak seluruhnya dapat membiayai total pengeluaran daerah, namun proporsi PAD terhadap total penerimaan daerah tetap merupakan indikasi derajat kemandirian keuangan suatu pemerintah daerah. Berdasarkan tinjauan pustaka dan konsep-konsep di atas, maka dapat dibangun kerangka pemikiran dan bagan alir pikir seperti pada Gambar 1.

\section{METODE PENELITIAN}

Penelitian ini dilaksanakan pada tahun 2012, dengan locus penelitian adalah PDAM Tirta 


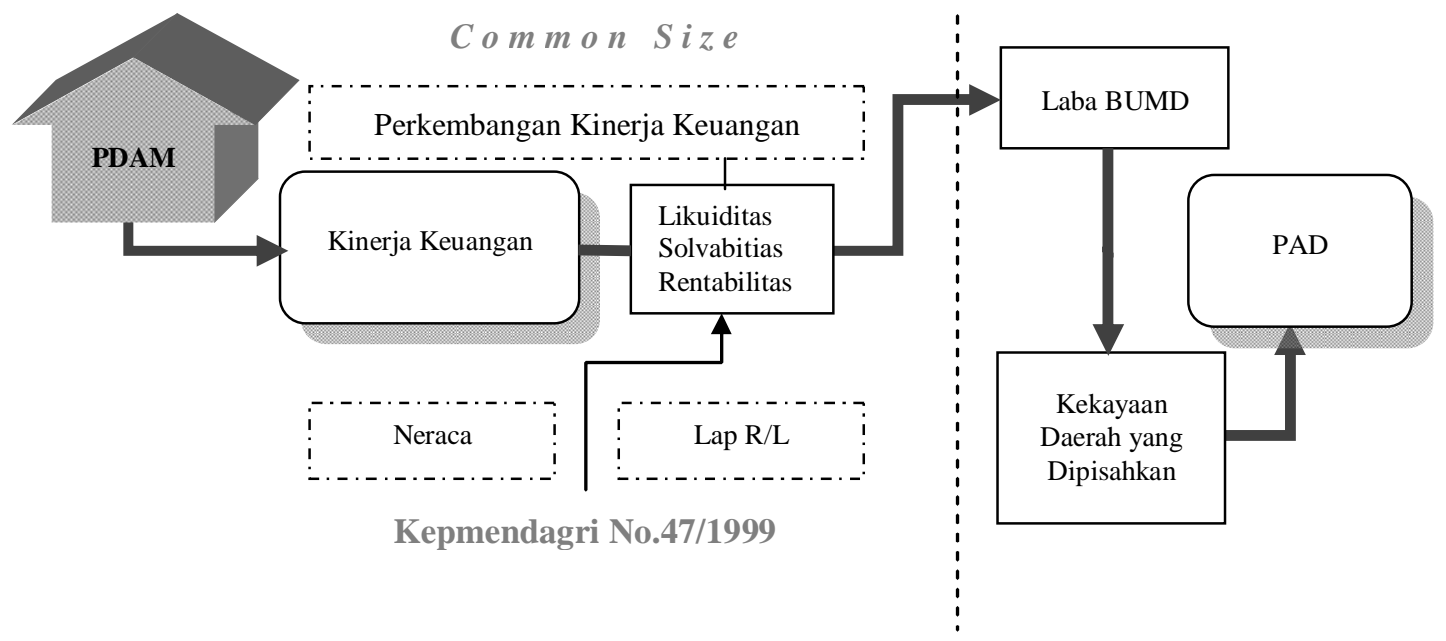

Gambar 1. Kerangka Pemikiran.

Perwitasari Kabupaten Purworejo, Jalan Jenderal Sudirman No. 101 Kabupaten Purworejo Provinsi Jawa Tengah 54114. antara lain:

Cara pengumpulan data dalam penelitian ini

a. Penelitian lapangan, dilakukan dengan mendatangi langsung terhadap obyek penelitian. Dalam penelitian ini dilakukan pengumpulan data dan informasi yang berkaitan dengan masalah penelitian baik data primer maupun data sekunder.

- Data primer, diambil berdasarkan hasil wawancara langsung dengan informan dan Focus Group Discussion (FGD) dengan para staf PDAM Tirta Perwitasari Kabupaten Purworejo mengenai hal-hal yang berkaitan dengan kinerja keuangan.

- Data sekunder, terdiri dari data laporan keuangan yang diperoleh langsung dari PDAM Tirta Perwitasari. Berupa Neraca dan Laporan Rugi-Laba time series 20062010.

b. Kepustakaan, dilakukan untuk mendapatkan landasan teori yang mendukung penelitian dan diambil dari literatur maupun buku-buku, artikel ilmiah serta hasil penelitian sebelumnya yang dapat menjawab pertanyaan penelitian.

c. Access internet, dilakukan untuk mendapatkan berbagai informasi terbaru dan lebih cepat diperoleh antara lain Peraturan Perundangundangan, jurnal-jurnal serta artikel-artikel.

Alat analisis yang dipergunakan di dalam penelitian ini adalah:

1. Keputusan Menteri Dalam Negeri (Kepmendagri) No. 47 Tahun 1999 tentang Pedoman Penilaian Kinerja Perusahaan Daerah Air Minum.
Penilaian terhadap kemampuan PDAM telah diatur dalam Kepmendagri No. 47 Tahun 1999 tentang Pedoman Penilaian Kinerja Perusahaan Daerah Air Minum. Menurut keputusan tersebut indikator penilaian kinerja PDAM dapat dilihat dalam tiga aspek; aspek keuangan, aspek operasional dan aspek administrasi. Di dalam aspek keuangan, terdapat beberapa rasio yang dapat dipergunakaan untuk mengukur kinerja keuangan dari berbagai indikator lainnya, seperti rasio laba terhadap aktiva produktif, rasio laba terhadap penjualan, rasio utang jangka panjang terhadap ekuitas dan lain-lain. Namun dalam penelitian ini hanya akan dilakukan analisa sederhana dari 3 (tiga) hal; yaitu likuiditas, solvabilitas dan rentabilitas kinerja keuangan PDAM.

2. Analisis Common Size

Untuk menafsirkan atau menginterpretasikan laporan keuangan yang dimiliki perusahaan, dari analisis Common Size ini dapat diketahui perkembangan perusahaan selama periode penelitian, yaitu dengan mengubah angka-angka yang ada di dalam laporan keuangan menjadi prosentase dengan dasar tertentu. Untuk angka-angka yang ada dalam neraca, common base-nya adalah total aktiva, artinya total aktiva diubah menjadi $100 \%$, sedangkan elemen-elemen yang lain akan mengikuti sesuai dengan proporsinya masingmasing (Sutrisno, 2003: 257).

Dalam penelitian ini terdapat beberapa indikator yang akan diamati untuk mengetahui kinerja PDAM Tirta Perwitasari Kabupaten Purworejo, yaitu dari variabel kinerja keuangan yang meliputi dua laporan utama. 
Tabel 2. Penilaian Kinerja Aspek Keuangan

\begin{tabular}{|c|c|c|c|c|c|}
\hline No. & Uraian & Formula & Rasio & Nilai & Kategori \\
\hline \multirow{5}{*}{1.} & Likuiditas: & Aktiva Lancar & $>1.75-2.00$ & 5 & Baik Sekali \\
\hline & Rasio Aktiva Lancar & Utang Lancar & $>1.50-1.75$ atau $>2.00-3.30$ & 4 & Baik \\
\hline & terhadap Utang Lancar & & $>1.25-1.50$ atau $>2.30-2.70$ & 3 & Cukup \\
\hline & & & $>1.00-1.25$ atau $>2.70-3.00$ & 2 & Kurang \\
\hline & & & $\leq 1.00$ atau $>3.00$ & 1 & Tidak Baik \\
\hline \multirow[t]{5}{*}{2.} & Solvabilitas: & Total Aktiva & $>2,0$ & 5 & Baik Sekali \\
\hline & Rasio Total Aktiva & $\overline{\text { Total Utang }}$ & $>1,7-2,0$ & 4 & Baik \\
\hline & terhadap Total Utang & & $>1,3-1,7$ & 3 & Cukup \\
\hline & & & $>1,0-1,3$ & 2 & Kurang \\
\hline & & & $\geq 1,0$ & 1 & Tidak Baik \\
\hline \multirow[t]{5}{*}{3.} & Rentablitas/Operating & $\underline{\text { Biaya Operasi }}$ & $\leq 0,50$ & 5 & Baik Sekali \\
\hline & rasio: & Pendapatan & $>0,50-0,65$ & 4 & Baik \\
\hline & Rasio biaya operasi & & $>0,65-0,85$ & 3 & Cukup \\
\hline & terhadap pendapatan & & $>0,85-1,00$ & 2 & Kurang \\
\hline & operasi & & $>1,00$ & 1 & Tidak Baik \\
\hline
\end{tabular}

Sumber: Kepmendagri No. 47 Tahun 1999.

Tabel 3. Rasio Aktiva Lancar terhadap Utang Lancar

\begin{tabular}{|cccccc|}
\hline Tahun & Aktiva Lancar $(\mathrm{Rp})$ & Utang Lancar $(\mathrm{Rp})$ & Rasio & Nilai & Kategori \\
\hline 2006 & $3.104 .126 .348,85$ & $374.142 .418,56$ & 8,3 & 5 & Baik Sekali \\
2007 & $4.192 .415 .524,77$ & $569.183 .133,79$ & 7,3 & 5 & Baik Sekali \\
2008 & $4.463 .964 .575 ., 61$ & $624.571 .676,24$ & 7,1 & 5 & Baik Sekali \\
2009 & $5.399 .249 .658,08$ & $625.329 .653,06$ & 8,6 & 5 & Baik Sekali \\
2010 & $5.284 .284 .231,49$ & $734.271 .337,77$ & 7,2 & 5 & Baik Sekali \\
\hline
\end{tabular}

Sumber: PDAM Tirta Perwitasari Kabupaten Purworejo, data diolah.

1. Neraca.

Neraca mempunyai dua sisi, sisi debit dan sisi kredit. Pada sisi debit menunjukkan posisi kekayaan perusahaan (aktiva) yang terdiri dari aktiva lancar dan aktiva tetap. Pada sisi kredit atau pasiva menunjukkan sumber kekayaan perusahaan yang terdiri dari dua sumber yakni utang dan modal.

2. Laporan Rugi-Laba.

Laporan ini bisa digunakan sebagai indikator keberhasilan perusahaan dalam menjalankan usahanya selama satu periode tertentu. Laporan rugi-laba pada dasarnya menggambarkan dua macam arus yang membentuk laba atau rugi.

\section{HASIL DAN PEMBAHASAN}

\section{Penilaian Kinerja Keuangan Berdasarkan Kepmendagri No. 47 Tahun 1999 tentang Pedoman Penilaian Kinerja Perusahaan Daerah Air Minum}

a. Rasio aktiva lancar terhadap utang lancar (likuiditas). Merupakan tolok ukur untuk menilai ketersediaan aset-aset likuid untuk memenuhi kewajiban jangka pendek dalam rangka membiayai kegiatan operasi maupun pembayaran utang dan bunga yang jatuh tempo jika ada.

Rasio aktiva lancar terhadap utang lancar (likuiditas) pada tabel 3, adalah hasil analisis data selama tahun 2006-2010. Pada tahun 2006 diperoleh rasio sebesar 8,3 yang berarti bahwa setiap utang lancar sebesar Rp 1,00 dijamin oleh aktiva lancar sebesar Rp 8,3. Tahun 2007 menurun menjadi sebesar 7,3 dan semakin menurun lagi menjadi sebesar 7,1 pada tahun 2008. Pada tahun berikutnya terjadi kenaikan rasio menjadi sebesar 8,6 atau terbesar selama periode tahun pengamatan. Namun, pada tahun 2010 terjadi penurunan lagi menjadi sebesar 7,2. Rasio ini dari tahun 2006-2008 cenderung menurun, menurunnya current ratio ini menunjukkan bahwa pada periode tersebut perusahaan likuiditasnya melemah untuk melunasi utang jangka pendeknya. Meskipun terjadi penurunan, namun masih mencerminkan adanya aktiva yang menganggur (idle) yang dapat dimanfaatkan untuk perputaran usaha karena perusahaan masih berada pada kategori 'Baik Sekali' bahkan pada seluruh periode pengamatan.

b. Rasio total aktiva terhadap total utang (solvabilitas). Rasio ini merupakan tolok ukur untuk menilai tingkat kecukupan dari seluruh aset yang tersedia dibandingkan dengan seluruh utang perusahaan, yang sekaligus mencerminkan jumlah aktiva netto (networth) yang tersedia.

Rasio total aktiva terhadap total utang adalah bagian dari setiap rupiah total aktiva untuk menjamin total utang yang digunakan untuk mendanai perusahaan. Tabel 4, adalah hasil analisis data selama tahun 2006-2010. 
Tabel 4. Rasio Total Aktiva terhadap Total Utang

\begin{tabular}{|cccccc|}
\hline Tahun & Total Aktiva $(\mathrm{Rp})$ & Total Utang $(\mathrm{Rp})$ & Rasio & Nilai & Kategori \\
\hline 2006 & $14.528 .514 .663,49$ & $2.268 .379 .970,36$ & 6,4 & 5 & Baik Sekali \\
2007 & $15.413 .209 .493,03$ & $2.951 .202 .864,25$ & 5,2 & 5 & Baik Sekali \\
2008 & $15.977 .644 .649,91$ & $3.519 .753 .686,76$ & 4,5 & 5 & Baik Sekali \\
2009 & $18.542 .967 .682,85$ & $3.857 .657 .096,32$ & 4,8 & 5 & Baik Sekali \\
2010 & $20.207 .300 .489,45$ & $4.073 .506 .988,33$ & 4,9 & 5 & Baik Sekali \\
\hline
\end{tabular}

Sumber: PDAM Tirta Perwitasari Kabupaten Purworejo, data diolah.

Tabel 5. Rasio Biaya Operasi terhadap Pendapatan Operasi

\begin{tabular}{|cccccc|}
\hline Tahun & Biaya Operasi $(\mathrm{Rp})$ & $\begin{array}{c}\text { Pendapatan Operasi } \\
(\mathrm{Rp})\end{array}$ & Rasio & Nilai & Kategori \\
\hline 2006 & $6.561 .538 .502,22$ & $6.251 .539 .662,00$ & 1,05 & 1 & Tidak Baik \\
2007 & $7.151 .910 .064,46$ & $7.634 .594 .884,00$ & 0,93 & 2 & Kurang \\
2008 & $8.653 .900 .299,12$ & $8.793 .966 .936,00$ & 0,98 & 2 & Kurang \\
2009 & $9.457 .250 .452,25$ & $9.906 .535 .600,00$ & 0,95 & 2 & Kurang \\
2010 & $10.431 .645 .995,66$ & $11.186 .387 .600,00$ & 0,93 & 2 & Kurang \\
\hline
\end{tabular}

Sumber: PDAM Tirta Perwitasari Kabupaten Purworejo, data diolah.

Menunjukkan pada tahun 2006 rasio yang diperoleh sebesar 6,4 yang artinya bahwa dari setiap Rp1,00 utang dijamin oleh Rp 6,4 aktiva. Pada tahun 2007 dan 2008 terjadi penurunan beturut-turut yaitu sebesar 5,2 dan 4,5. Beranjak naik pada tahun berikutnya yaitu tahun 2009 sebesar 4,8 dan 4,9 pada tahun 2010. Nilai yang diperoleh pada setiap tahun pengamatan adalah maksimal. Meskipun nilai yang diperoleh adalah maksimal, namun terdapat indikasi penurunan pada tahun-tahun terakhir yang sebaiknya menjadi perhatian, hal ini disebabkan karena proporsi kenaikan total utang tidak sebanding dengan kenaikan total aktiva.

c. Rasio biaya operasi terhadap pendapatan operasi (rentabilitas/operating ratio). Merupakan tolok ukur untuk menilai efisiensi/kehematan dalam penggunaan sumber dana dan daya untuk menjalankan kegiatan operasional perusahaan.

Rasio biaya operasi terhadap pendapatan operasi adalah biaya operasi per rupiah penjualan. Asumsinya semakin tinggi rasio tersebut semakin tidak baik. Rasio yang baik adalah $\leq 0,50$ atau setiap pendapatan mempunyai biaya operasi paling tinggi $50 \%$. Tabel 5 , adalah hasil analisis data selama tahun 2006-2010. Menunjukkan pada tahun 2006 rasio yang diperoleh sebesar 1,05; artinya bahwa dari setiap Rp1,00 pendapatan operasi mempunyai biaya operasi sebesar Rp1,05. Rasio yang diperoleh > 1 (satu) menunjukkan bahwa perusahaan mengalami kerugian, yaitu pada tahun 2006 tersebut. Untuk tahun 2007 rasio < 1 (satu) yaitu 0,93; tahun 2008 rasio sedikit meningkat menjadi sebesar 0,98. Pada tahun 2009 membaik menjadi sebesar 0,95; kemudian pada periode akhir tahun pengamatan 2010 kembali kepada angka rasio sebesar 0,93. Ini menunjukkan bahwa perusahaan telah memperoleh laba pada 4 (empat) tahun-terakhir.

- Pada tahun awal pengamatan atau tahun 2006, perusahaan menghasilkan nilai yang tidak baik, hal ini mengindikasikan perusahaan mengalami rugi operasi.

- Mulai tahun 2007 perusahaan dapat memperoleh nilai kinerja yang lebih baik, yaitu dalam kategori kurang, karena ada usaha untuk melakukan penghematan biaya operasi dan peningkatan pendapatan operasi.

- $\quad$ Sesuai Kepmendagri No. 47 Tahun 1999, bahwa tingkat efisiensi diperoleh apabila nilai rasio antara biaya operasi dengan pendapatan operasi adalah sebesar $\leq 0,50$ atau $\leq 50 \%$, yang berarti jika realisasi pendapatan operasi pada tahun 2006 sebesar Rp 6.251.539.662,00; maka biaya operasional yang seharusnya dikeluarkan adalah sebesar $\leq \operatorname{Rp~3.125.769.831,00;~}$ namun ternyata bahwa biaya operasi yang dikorbankan adalah sebesar Rp 6.561.538.502,22; sehingga terdapat kelebihan biaya operasional sebesar $\geq \mathrm{Rp}$ 3.435.768.671,22 atau $\geq 52,36 \%$. Untuk tahun 2007 dan seterusnya, meskipun ada pada kategori yang lebih baik, tetap masih terdapat kelebihan biaya operasional dari yang seharusnya dikeluarkan.

Dikutip dari tulisan Imam (2007) yang diberitakan dalam purworejonews, bahwa untuk menutup defisit, tahun 2006 PDAM mendapat subsidi I sebesar Rp 500.000.000,00 melalui APBD Perubahan. Namun pada penyusunan APBD 2007 tidak diusulkan subsidi lagi sehingga untuk menutup defisit harus menaikkan tarif, yang ditindaklanjuti dengan dikeluarkannya Peraturan Bupati (Perbup) Purworejo No. 5.A 
Tabel 6. Perkembangan Neraca berdasarkan analisis Common Size (\%)

\begin{tabular}{|llllll|}
\hline Perkiraan & 2006 & 2007 & 2008 & 2009 & 2010 \\
\hline Jumlah Aktiva Lancar & 21,36 & 27,20 & 27,93 & 29,11 & 26,15 \\
Kas & 12,63 & 11,35 & 11,74 & 14,35 & 6,60 \\
Deposito Berjangka/investasi jk. pendek & 2,85 & 7,88 & 8,85 & 7,63 & 11,95 \\
Piutang Usaha & 5,12 & 6,94 & 6,47 & 6,54 & 7,22 \\
Piutang Pajak & 0,19 & 0,22 & 0,84 & 0,00 & - \\
Piutang lain-lain (pegawai) & 0,003 & - & - & - & - \\
Persediaan & 0,63 & 0,65 & 0,83 & 7,61 & 0,54 \\
Pembayaran dimuka & 0,07 & 0,37 & 0,93 & 0,02 & 0,07 \\
\hline Jumlah Aktiva Tetap & 47,65 & 43,62 & 43,11 & 44,90 & 50,96 \\
\hline Jumlah Aktiva Lain-lain & 30,98 & 29,17 & 28,94 & 26,28 & 23,23 \\
\hline Jumlah Aktiva & 100 & 100 & 100 & 100 & 100 \\
\hline Jumlah Kewajiban Jangka Pendek & 2,57 & 3,69 & 3,90 & 3,37 & 3,63 \\
Utang Usaha & 0,77 & 0,68 & 0,70 & 1,22 & 0,22 \\
Biaya yang masih harus dibayar & 0,96 & 1,20 & 1,64 & 1,49 & 1,23 \\
Utang Pajak & 0,14 & 1,03 & 3,25 & 0,34 & 0,39 \\
Utang pada Pemda & 0,65 & 0,71 & 1,18 & 0,00 & - \\
Utang Jangka Pendek Lainnya & 0,04 & 0,05 & 0,05 & 0,05 & 1,67 \\
\hline Jumlah Kewajiban Jangka Panjang & - & - & - & - & - \\
\hline Jumlah Kewajiban Lain-lain & 13,03 & 15,45 & 18,12 & 17,43 & 16,52 \\
\hline Jumlah Ekuitas & 84,38 & 80,85 & 77,97 & 76,15 & 78,47 \\
\hline Total Pasiva & 100 & 100 & 100 & 100 & 100 \\
\hline Sumbr PDAM Tira Perwitas
\end{tabular}

Sumber: PDAM Tirta Perwitasari Kabupaten Purworejo, data diolah.

Tabel 7. Perkembangan Laporan Rugi-Laba berdasarkan analisis Common Size (\%)

\begin{tabular}{|c|c|c|c|c|c|}
\hline $\begin{array}{l}\text { Perkiraan } \\
\end{array}$ & 2006 & 2007 & 2008 & 2009 & 2010 \\
\hline Jumlah Pendapatan Usaha & 100 & 100 & 100 & 100 & 100 \\
\hline Penjualan Air & 94,42 & 95,36 & 93,84 & 92,22 & 90,37 \\
\hline Penjualan Non Air & 5,58 & 4,64 & 6,16 & 7,78 & 9,62 \\
\hline Jumlah Biaya Usaha & 104,94 & 93,65 & 98,38 & 95,44 & 93,84 \\
\hline Biaya Sumber & 39,54 & 31,46 & 27,83 & 27,98 & 22,27 \\
\hline Biaya Pengolahan & 12,55 & 12,69 & 21,88 & 17,16 & 15,87 \\
\hline Biaya Transmisi \& Distribusi & 14,87 & 14,44 & 14,28 & 14,57 & 13,68 \\
\hline Biaya Umum \& Administrasi & 37,98 & 35,06 & 34,39 & 35,73 & 42,02 \\
\hline Laba (Rugi) Usaha & $(4,95)$ & 6,35 & 1,62 & 4,56 & 6,16 \\
\hline
\end{tabular}

Sumber: PDAM Tirta Perwitasari Kabupaten Purworejo, data diolah.

Tahun 2007 tentang Tarif Air Minum Perusahaan Daerah Air Minum Tirta Perwitasari Kabupaten Purworejo. Langkah ini terbukti manjur untuk meningkatkan rasio rentabilitas hingga tahun-tahun berikutnya.

\section{Perkembangan Kinerja Keuangan Berdasarkan Analisis Common Size}

Pada Tabel 6 dirinci perkembangan persentase

(\%) tiap komponen neraca berdasarkan analisis Common Size. Dari Tabel 6, dapat dijelaskan berbagai hal sebagai berikut.

a. Aktiva lancar pada periode pengamatan tahun 2006-2010 dari data tersebut di atas, menunjukkan adanya peningkatan dari $21,36 \%$ menjadi sebesar $26,15 \%$ dari jumlah total aktiva.

b. Aktiva tetap yang merupakan nilai perolehan dan akumulasi penyusutan mengalami kenaikan dari $47,65 \%$ menjadi sebesar $50,96 \%$.

c. Aktiva lain-lain yang terdiri dari bahan instalasi, sisa uang muka kepada Pemda, uang jaminan pelanggan dan aktiva tetap yang tidak digunakan mengalami penurunan dari 30,98\% menjadi sebesar $23,23 \%$.

d. Pada sisi pasiva, kewajiban jangka pendek menunjukkan kenaikan dari $2,57 \%$ menjadi sebesar 3,63\% dari jumlah total kewajiban dan modal.

e. Perusahaan tidak mempunyai kewajiban jangka panjang yang harus dilunasi karena tidak memiliki utang.

f. Kewajiban lain-lain yang terdiri dari uang jaminan langganan, cadangan dana (jasa produksi, sosial dan pendidikan) dan sumbangan dana pensiun, mengalami kenaikan dari sebesar $13,03 \%$ menjadi sebesar $16,52 \%$.

g. Jumlah ekuitas mengalami penurunan dari $84,38 \%$ menjadi sebesar $78,47 \%$.

Pada Tabel 7 dirinci perkembangan persentase (\%) tiap komponen laporan rugi-laba berdasarkan analisis Common Size. Dari tabel tersebut dapat dijelaskan berbagai hal sebagai berikut. 
a. Jumlah pendapatan usaha perusahaan, terdiri atas penjualan air dan non air. Pengamatan tahun 2006-2010 pada penjualan air menunjukkan penurunan dari 94,42\% menjadi sebesar $90,37 \%$, sedangkan pada penjualan non air mengalami kenaikan dari 5,58\% menjadi sebesar 9,62\%.

b. Jumlah biaya usaha dari periode pengamatan tahun 2006-2010 menunjukkan adanya penurunan dari sebesar $104,94 \%$ menjadi sebesar $93,84 \%$.

c. Laba (rugi) usaha, pada periode pengamatan tahun 2006-2010 menunjukkan perubahan yang fluktuatif. Pada tahun 2006, perusahaan mengalami kerugian dari sebesar $-4,94 \%$. Tahun 2007-2010 perusahaan memperoleh laba, namun perolehan laba tersebut dari tahun ke tahun mengalami fluktuasi dari $6,35 \%, 1,62 \%, 4,56 \%$ dan terakhir menjadi sebesar $6,16 \%$.

\section{SIMPULAN}

Dari hasil penelitian dan pembahasan, penilaian kinerja keuangan PDAM Tirta Perwitasari berdasarkan Kepmendagri No. 47 Tahun 1999 diperoleh beberapa kesimpulan sebagai berikut. Likuiditas perusahaan. Sejak tahun 2006-2010 current ratio perkembangannya adalah 8,$3 ; 7,3 ; 7,1 ; 8,6$ dan 7,2. Hal ini berarti secara keseluruhan dapat dikatakan bahwa perusahaan sangat likuid untuk melunasi utangutang jangka pendeknya, bahkan untuk tahun tertentu seperti pada tahun 2006 dan tahun 2009, perusahaan cenderung terlalu likuid yang mencerminkan adanya aktiva lancar atau dana yang menganggur (idle capacity). Solvabilitas perusahaan. Sejak tahun 20062010 assets to debt ratio perkembangannya adalah 6,$4 ; 5,2 ; 4,5 ; 4,8$ dan 4,9. Hal ini berarti secara keseluruhan perusahaan sangat mampu melunasi utang-utangnya apabila perusahaan dilikuidasi, sebab utang-utangnya masih tertutup oleh kekayaannya atau dapat dikatakan bahwa perusahaan dalam kondisi solvable. Rentabilitas/Operating ratio. Sejak tahun 2006-2010 perkembangannya adalah 1,$05 ; 0,93 ; 0,98$; 0,95 dan 0,93. Hal ini berarti bahwa pada tahun 2006 perusahaan mengalami kerugian sebesar 5\%, kemudian pada tahun 2007-2010 perusahaan memperoleh laba sebesar $7 \%, 2 \%, 5 \%$ dan $7 \%$. Selama periode pengamatan tahun 2006-2010, terdapat kelebihan biaya operasional dari yang seharusnya $(\leq 50 \%)$ setiap tahunnya. Selanjutnya perkembangan kinerja keuangan PDAM Tirta Perwitasari berdasarkan analisis Common Size, secara garis besar dapat dijelaskan perkembangannya bahwa perusahaan pada tahun 2006 mengalami kerugian usaha, baru kemudian memperoleh laba usaha mulai tahun 2007-2010.

Berdasarkan analisa dan kesimpulan, PDAM Tirta Perwitasari sebaiknya memanfaatkan idle capacity untuk perputaran usaha; mendayagunakan kondisi solvable untuk perluasan cakupan layanan dan melakukan efisiensi biaya operasional untuk menurunkan rasio rentabilitas. Terkait dengan kontribusinya terhadap laba BUMD, berdasarkan analisis kinerja keuangan 2006-2010, terlihat bahwa sesunguhnya PDAM Tirta Perwitasari Kabupaten Purworejo untuk saat ini belum mampu untuk memenuhi tuntutan tersebut. Selain masih lemah pada sisi rentabilitas, PDAM Tirta Perwitasari cakupan pelayanannya belum mencapai $80 \%$ dari jumlah penduduk dalam wilayah administratif daerah kabupaten. Hal ini sebagaimana termaktub di dalam Surat Edaran (SE) Mendagri No. 690/477/SJ tanggal 18 Februari 2009 perihal Percepatan terhadap Program Penambahan 10 juta Sambungan Rumah Air Minum Tahun 2009 s/d 2013. Oleh karena itu, untuk PDAM yang belum memenuhi kebutuhan diatas, sebaiknya tidak dituntut berkontribusi pada PAD, namun agar laba yang diperoleh diupayakan untuk direinvestasikan dalam rangka meningkatkan kualitas dan jangkauan pelayanan (Permendagri No. 25 Tahun 2009 tentang Pedoman Penyusunan Anggaran Pendapatan dan Belanja Daerah Tahun Anggaran 2010 lampiran II, 1, a, 5).

\section{DAFTAR PUSTAKA}

Helfert, E. A. 1995. Teknik Analisa Keuangan. Edisi ke7. Jakarta: Erlangga.

Imam, Ahmad Nas. 2007. Tahun 2007 Tarif PDAM Naik. http://purworejonews.com/index.php? option=com content $\&$ task=view\&id=70\&Itemid $=1$ (diakses 15 Oktober 2012)

Jusup, Al Haryono. 2003. Dasar-dasar Akuntansi Jilid 1. Edisi ke-6. Yogyakarta: Bagian Penerbitan Sekolah Tinggi Ilmu Ekonomi YKPN.

Keputusan Menteri Dalam Negeri Nomor 47 Tahun 1999 tentang Pedoman Penilaian Kinerja Perusahaan Daerah Air Minum.

Munawir, Slamet. 2004. Analisis Laporan Keuangan. Yogyakarta: Liberty.

Peraturan Daerah Kabupaten Purworejo Nomor 15 Tahun 2011 tentang Perusahaan Daerah Air Minum Tirta Perwitasari.

Rachmawati, Noer. 2001. Kinerja PDAM Delta Tirta dan Faktor-faktor yang mempengaruhinya (studi kasus) di Kabupaten Sidoarjo. Tesis S2 Program Pascasarjana UGM (tidak dipublikasikan).

Rismianto, Djoko. 2001. Sumbang Pikir: Menuju Kemandirian PDAM. Bulletin Bapekin. (http://www.pu.go.id/bapekin/buletin\%20jurnal/b uletin\%206/buletin64, diakses Juli 2005)

Sefraningsih. 2001. Kinerja Perusahaan Daerah Air Minum Tirta Musi Kabupaten Rejang Lebong. Tesis S2 Program Pascasarjana UGM (tidak dipublikasikan).

Suhendra, Zulfi. 2012. Boediono: Dari 300 PDAM, Cuma 1/4 Yang Sehat. Jakarta: detik.com.(http://finance.detik.com/read/2012/07/ 11/132918/1962858/4/boediono-dari-300-pdamcuma-1-4-yang-sehat, diakses 8 Agustus 2012)

Sutrisno. 2003. Manajemen Keuangan Teori, Konsep dan Aplikasi. Edisi Pertama. Yogyakarta: Ekonisia. 
Wahyudin, M. dan Muryati, A. 2001. Faktor-faktor yang Mempengaruhi Kepuasan Pelanggan

Perusahaan Daerah Air Minum (PDAM) Kabupaten Klaten. Jurnal Manajemen Dayasaing 2. Surakarta: Universitas Muhammadiyah Surakarta. 
